\title{
KEHIDUPAN MASA PROTOSEJARAH DI SITUS MOSANDUREI, NABIRE (Protohistory Life in the Mosandurei Site, Nabire)
}

\author{
Hari Suroto \\ Balai Arkeologi Jayapura, Jalan Isele, Kampung Waena, Jayapura 99358 \\ Telepon (0967) 572467, Faksimile (0967) 572467, hariprimitiveart@gmail.com
}

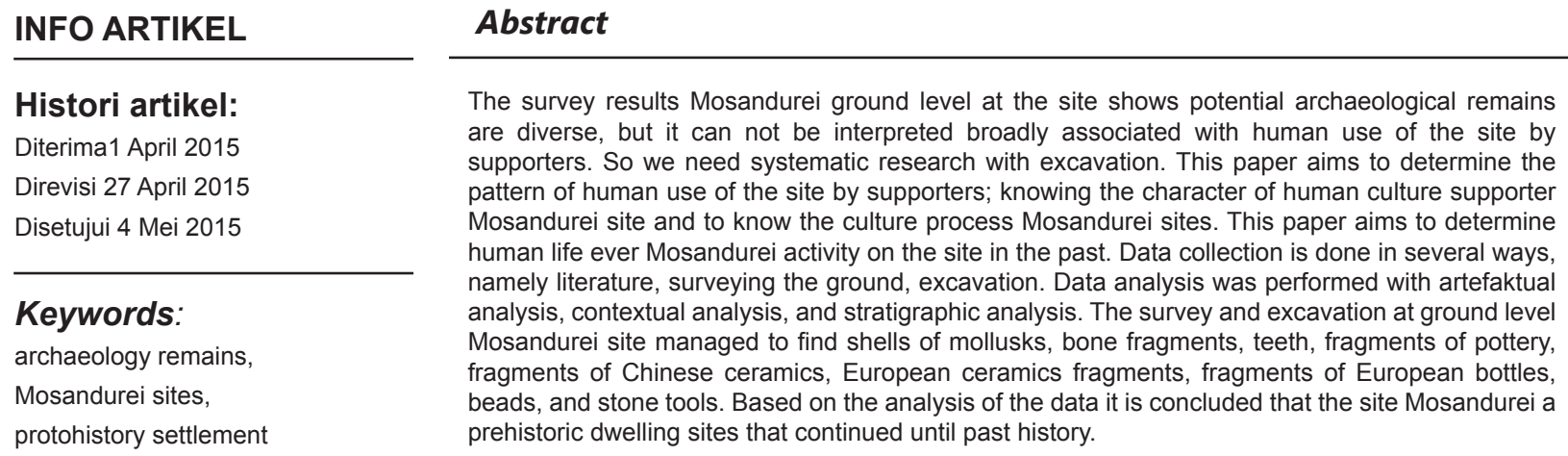

Kata kunci:

\begin{abstract}
Abstrak
Hasil survei permukaan tanah di situs Mosandurei menunjukkan potensi tinggalan arkeologi yang beragam, namun hal ini belum dapat menginterpretasikan secara luas terkait dengan pemanfaatan situs oleh manusia pendukungnya. Oleh karena itu, penelitian yang sistematis dengan ekskavasi perlu dilakukan. Tulisan ini bertujuan untuk mengetahui kehidupan manusia yang pernah beraktivitas di situs Mosandurei pada masa lampau. Kajian tulisan ini dilakukan dengan pengumpulan data dan analisis data. Pengumpulan data dilakukan dengan beberapa cara, yaitu studi pustaka, survei permukaan tanah, ekskavasi. Analisis data dilakukan dengan analisis artefaktual, analisis kontekstual, dan analisis stratigrafis. Hasil survei permukaan tanah dan ekskavasi di situs Mosandurei berhasil menemukan cangkang moluska, fragmen tulang, gigi, fragmen gerabah fragmen keramik Cina, fragmen keramik Eropa, fragmen botol Eropa, manik-manik, dan alat batu. Berdasarkan analisis data maka diinterpretasikan bahwa situs Mosandurei merupakan situs hunian prasejarah yang berlanjut hingga masa sejarah.
\end{abstract}

tinggalan arkeologi,

Situs Mosandurei,

hunian protosejarah

\section{PENDAHULUAN}

Nabire terletak di kawasan Teluk Cenderawasih. Nabire terdiri atas daratan dan perairan dengan gugusan pulau-pulau kecil (http://nabirekab. go.id). Wilayah Nabire memiliki potensi tinggalan arkeologi yang tinggi. Eksplorasi arkeologi tahun 2011 di Napan, Nabire oleh Balai Arkeologi Jayapura berhasil menemukan situs Mosandurei dengan temuan sisa sampah kerang, fragmen keramik Cina, fragmen keramik Eropa, manik-manik, fragmen gerabah, fragmen tulang manusia, fragmen besi dan calon alat batu (Fairyo dan Tolla, 2011: 18).

Keletakan Nabire sangat strategis berada di pertengahan pesisir utara Papua. Perairan Nabire memiliki moluska yang beragam, dan dimanfaatkan oleh penduduk setempat sebagai sumber pangan maupun diperdagangkan. Menurut Muller (2008:74) cangkang kerang cowries yang dimanfaatkan sebagai alat tukar di kawasan Danau Paniai sebagian berasal dari wilayah 
pesisir Teluk Cenderawasih. Diperkirakan jalur perdagangan kerang cowries ini mula-mula masuk melalui Nabire terus ke wilayah Danau Paniai. Selain itu, berdasarkan letak strategisnya, pulau-pulau di Teluk Cenderawasih diasumsikan menjadi tempat-tempat utama dari jaringan perdagangan jarak jauh. Hal ini didasari oleh keramik yang berasal dari luar dijadikan sebagai mas kawin di Biak, Numfor, dan Yapen. Namun demikian, asumsi ini masih perlu dibuktikan dengan penggalian arkeologis.

Banyaknya temuan gerabah di situs prasejarah, dapat memberi gambaran bahwa gerabah merupakan salah satu jenis barang atau benda yang sangat diperlukan dalam kehidupan masa prasejarah. Berdasarkan hal itu, maka manusiamasalampau berupaya mencari jalan agar kebutuhan akan gerabah dapat terpenuhi. Upaya memenuhi kebutuhan dengan dua cara, pertama adalah upaya menciptakan sendiri, bagi komunitas yang berdiam di wilayah yang menyediakan bahan, sedangkan cara kedua adalah melakukan hubungan antar komunitas, yakni bila daerahnya tidak memiliki bahan pembuatan gerabah (Atmosudiro, 1995:123).

Butzer (1964:337) menyatakan bahwa kondisi lingkungan dapat dianggap sebagai salah satu faktor penentu dalam pemilihan lokasi situs. Beberapa variabel yang berhubungan dengan kondisi lingkungan tersebut antara lain: a. tersedianya kebutuhan akan air, adanya tempat berteduh, dan kondisi tanah yang tidak terlalu lembab; b. tersedianya fasilitas-fasilitas yang diperlukan untuk bergerak lebih mudah (pantai, sungai, lerengan); c. tersedianya sumber makanan baik berupa flora dan fauna serta faktorfaktor yang memberi kemudahan di dalam cara-cara perolehannya (tempat untuk minum binatang, batas-batas topografik, pola vegetasi); d. faktorfaktor yang memberi elemen tambahan akan binatang laut atau binatang air (dekat pantai, danau, sungai, mata air).

Salah satu bentuk perilaku ekonomi yang paling awal dalam kebudayaan adalah pertukaran (exchange). Dari segi proses, pertukaran adalah penyebaran benda secara keruangan, dari individu ke individu lain, dan dari satu kelompok ke kelompok lain (Earle, 1982: 45). Studi pertukaran mencoba untuk selalu dapat memahami proses yang berlangsung dalam pemindahan barang dari satu tangan ke tangan lain dan dari satu kelompok manusia ke kelompok manusia yang lain.

Selama ini interpretasi terhadap artefak keramik yang ditemukan di suatu situs selalu mengarah kepada kontak antara orang asing dan lokal. Asumsi lainnya, bahwa keramik tersebut dibawa oleh pedagang Cina itu sendiri ke situs. Padahal, berdasarkan data kesejarahan belum tentu keramik tersebut dibawa langsung oleh pedagang Cina ke situs (Nayati, 1995:97).

Arkeologi berupaya untuk menjembatani kesenjangan dalam memahami proses yang muncul diantara perilaku manusia dan budaya bendawi. Schiffer (1976: 69) menguraikan proses panjang suatu artefak dari konteks sistemnya ke konteks arkeologi. Proses tersebut menuntut arkeolog berhatihati dalam menafsirkan archaeological 
records, sehubungan rekonstruksi sistem budaya.

Secara umum, situs-situs arkeologi dapat diklasifikasi menjadi dua tipe, yaitu stratified sites dan surface sites. Stratified sites adalah situs-situs yang secara geologik berada dalam konteks langsung, sedang surface sites adalah situs-situs yang berada diatas permukaan tanah, tanpa konteks geologik. Kedua tipe situs ini dapat diklasifikasi dalam berbagai cara. Berdasarkan fungsi dan jenis aktivitasnya, situs-situs arkeologi dapat dibedakan menjadi: situs hunian, situs perdagangan, situs penambangan, situs penguburan, situs seremonial dan situs perbengkelan (Sharer \& Ashmore, 1979: 68-100).

Hasil penelitian tahun 2011, menunjukkan temuan permukaan tanah di situs Mosandurei lebih beragam, terutama terdapat deposit sampah kerang dalam jumlah banyak. Berdasarkan hal tersebut, Tim Penelitian merekomendasikan untuk melakukan ekskavasi di situs Mosandurei (Fairyo dan Tolla, 2011: 29).

Penelitian arkeologi tahun 2011 di situs Mosandurei, lebih ditekankan untuk mengetahui potensi arkeologi yang ada di permukaan tanah, namun hal ini belum dapat menginterpretasikan secara luas terkait dengan kehidupan manusia pendukungnya pada masa lampau.

Untuk itu perlu dilakukan penelitian yang sistematis dengan ekskavasi. Jika dikaitkan dengan tujuan ilmu arkeologi mengandung pemahaman yang berlandaskan kepada tiga paradigma kebudayaan (Binford, 1972: 78), data arkeologi yang diperoleh, dipergunakan sebagai bahan dalam merekonstruksi kehidupan manusia yang pernah beraktivitas di situs Mosandurei pada masa lampau.

\section{METODE}

Penelitian ini dilakukan dengan pengumpulan data dan analisis data. Pengumpulan data dilakukan dengan beberapa cara, yaitu:

a. Studi pustaka berupa penelusuran data baik itu sumber dari internet maupun literatur yang berkaitan dengan situs sebagai bahan acuan dalam pembuatan desain dan strategi pelaksanaan penelitian yang nantinya dapat menjadi panduan dalam kegiatan penelitian.

b. Survei di situs dengan cara mengamati permukaan tanah dari jarak dekat, dilakukan juga survei permukaan di lingkungan sekitar situs untuk mendapatkan data arkeologi dalam konteks dengan lingkungan sekitarnya, dan untuk mengetahui hubungan antardata arkeologi (Redaksi, 2008:22). Survei ini digunakan dalam penentuan batas situs, persebaran temuan permukaan, pengambilan contoh (sampling) temuan permukaan, dan menetapkan keletakan kotak yang akan digali.

c. Ekskavasi adalah salah satu teknik pengumpulan data melalui penggalian tanah yang sistematik untuk menemukan suatu atau himpunan tinggalan arkeologi dalam situasi insitu. Dengan ekskavasi diharapkan akan diperoleh keterangan mengenai bentuk temuan, hubungan antartemuan, hubungan stratigrafis, hubungan kronologis, tingkah laku manusia pendukungnya serta 
aktivitas, alam dan manusia setelah temuan terdepositkan (Redaksi, 2008:311). Ekskavasi yang dilakukan ini menggunakan sistem kotak (box system), yaitu pembuatan kotak galian yang bentuk dasarnya segi empat, dengan luas yang dipatok dan digali seluas $1 \times 1$ meter. Ekskavasi menggunakan teknik spit, yaitu menggali tanah secara arbitrer (arbitrary level) dengan interval ketebalan $10 \mathrm{~cm}$.

Analisis data dilakukan dengan analisis artefaktual, yaitu mengamati ciri-ciri fisik artefak dari aspek bentuk, ukuran, warna, teknologi dan gaya. Selain itu juga dilakukan analisis kontekstual (contextual analysis), yaitu mencari korelasi data artefak dengan temuan serta, dalam satu matriks (association), baik artefak maupun ekofak.

Pengamatan juga dilakukan pada keletakan data arkeologi (provenience), persebaran temuan dalam ruang (distribution) dan lapisan tanah (stratification).

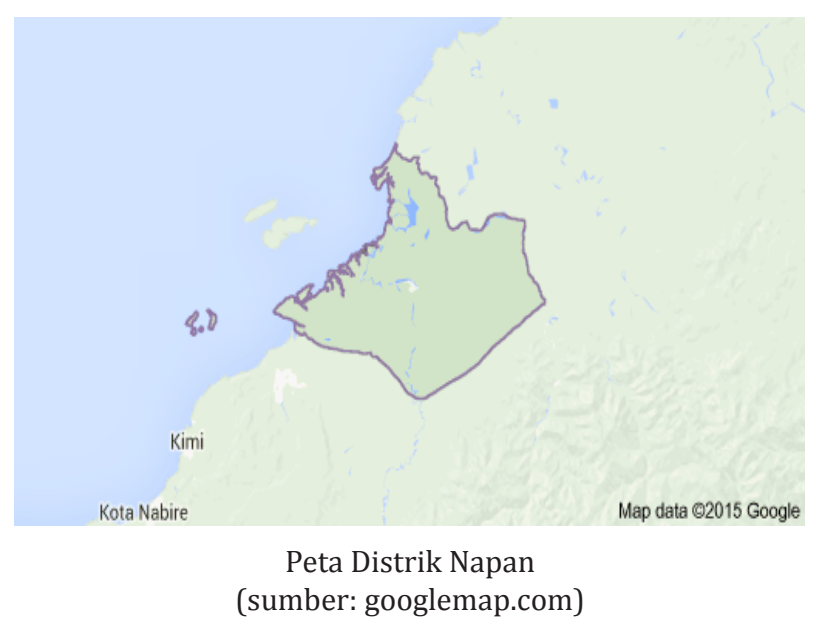

\section{PEMBAHASAN}

Situs Mosandurei secara administratif berada di Kampung Mosan, Distrik Napan, Kabupaten Nabire. Secara geografis situs Mosandurei terletak pada $03^{\circ} 04^{\prime} 10.1$ " LS dan $135^{\circ} 45^{\prime} 08.6^{\prime \prime}$ BT. Luas situs mencapai $250 \times 500$ meter. Secara topografi situs Mosandurei terletak di atas bukit Mosandurei, berorientasi barat - timur. Bentang lahan sekitar situs terdiri atas hutan dengan beraneka vegetasi flora dan berbagai jenis fauna di sebelah utara. Sebelah timur situs terdapat jurang yang berbatasan dengan situs Koan. Sebelah selatan situs terdapat hutan sagu dan Sungai Lagari, sebelah barat berbatasan dengan hutan. Permukaan situs ditumbuhi oleh semak belukar dan pepohonan.

Survei permukaan tanah dan ekskavasi di Situs Mosandurei berhasil menemukan artefak yaitu fragmen gerabah, fragmen keramik Cina, fragmen keramik Eropa, fragmen botol Eropa, manik-manik, dan alat batu. Selain itu juga ditemukan ekofak berupa cangkang moluska, fragmen tulang, gigi, dan arang.

\section{- Ragam jenis gerabah dan fungsinya}

Fungsi gerabah ditentukan oleh bentuk dan konteksnya. Oleh sebab itu analisis gerabah dalam penelitian ini diarahkan pada upaya mengenali kembali bentuk-bentuk gerabah yang ditemukan. Hal ini dilakukan mengingat sebagian besar gerabah yang ditemukan dalam bentuk pecahan. Selain itu analisis juga diarahkan pada upaya mengenali aspek kontekstualnya. 
Pengamatan terhadap pecahan gerabah bagian tepian dan dasar, diketahui bentuk utuh wadah yaitu periuk, tempayan dan forna. Bentuk badan periuk bulat, badan melebar di bagian bawah menyempit di bagian atasnya, bagian dasar membulat, dan cekung. Forna terdiri dua bentuk, forna persegi panjang dan forna setengah bulat. Analisis teknik pembuatan gerabah dilakukan dengan mengamati jejak pembentuk dinding bagian luar atau bagian dalam.

Gerabah jenis periuk dibuat dengan teknik pijit. Jejak teknik pembuatan periuk terlihat pada permukaan luar maupun yang tidak rata serta jejak jari tangan (fingermark). Irisan gerabah periuk warna merah atau coklat yang tidak merata mengindikasikan tingkat pembakaran pada tahap reduksi. Gerabah periuk juga dibakar di tempat terbuka. Periuk ini dibuat dari tanah liat yang dicampur dengan pasir kuarsa halus.

Pembuatan gerabah jenis tempayan menggunakan teknik tatap pelandas. Jejak teknik pembuatan terlihat pada permukaan bagian dalam gerabah, berupa cekungan yang cukup besar dan pada permukaan luar berupa bekas pemukul. Pengamatan pada irisan fragmen tempayan berwarna hitam yang tidak merata, mengindikasikan tingkat pembakaran pada tahap reduksi. Pembakaran di tempat terbuka (open fire). Tempayan dibuat dari tanah liat yang dicampur dengan pasir kuarsa kasar.

Tempayan digunakan

untuk menyimpan air dan menyimpan pati sagu. Dinding tempayan yang tebal, memiliki daya tahan yang kuat sebagai media penyimpan. Periuk digunakan untuk merebus air, merebus umbi-umbian, dan merebus kerang. Dinding periuk yang tipis, mempercepat dalam proses pemanasan makanan.

Forna merupakan tungku untuk memanggang tepung sagu. Forna ini terdiri dari enam atau delapan bilik untuk menaruh tepung sagu. Teknik pembuatan forna yaitu teknik pijit dan lempeng. Bahan pembuat forna yaitu tanah liat campur pasir kuarsa kasar.

Temuan fragmen gerabah forna mengindikasikan bahwa telah ada aktivitas pengolahan bahan pangan yang lebih variatif yaitu memanggang tepung sagu atau sagu bakar. Untuk membuat sagu bakar, sagu mentah yang masih basah dipecah-pecah, lalu dijemur di panas matahari, dibuat tepung lalu diayak. Forna diletakkan di atas bara sabut kelapa. Kemudian forna yang sudah merah membara diangkat dengan capitan bambu, dan diletakkan di atas tanah. Tepung sagu dituangkan ke dalam lempengan forna, satu demi satu. Sagu lempeng matang tidak dengan cara dipanggang di atas api, tetapi kematangannya tercipta lewat proses transfer panas melalui tanah liat sebagai mediumnya.

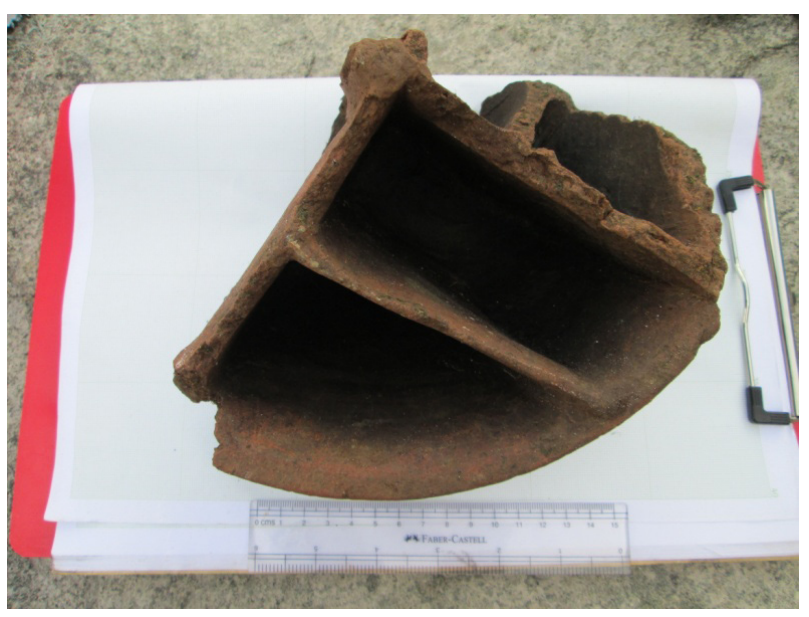

Gambar 1. Fragmen forna setengah bulat (dokumentasi Balai Arkeologi Jayapura) 


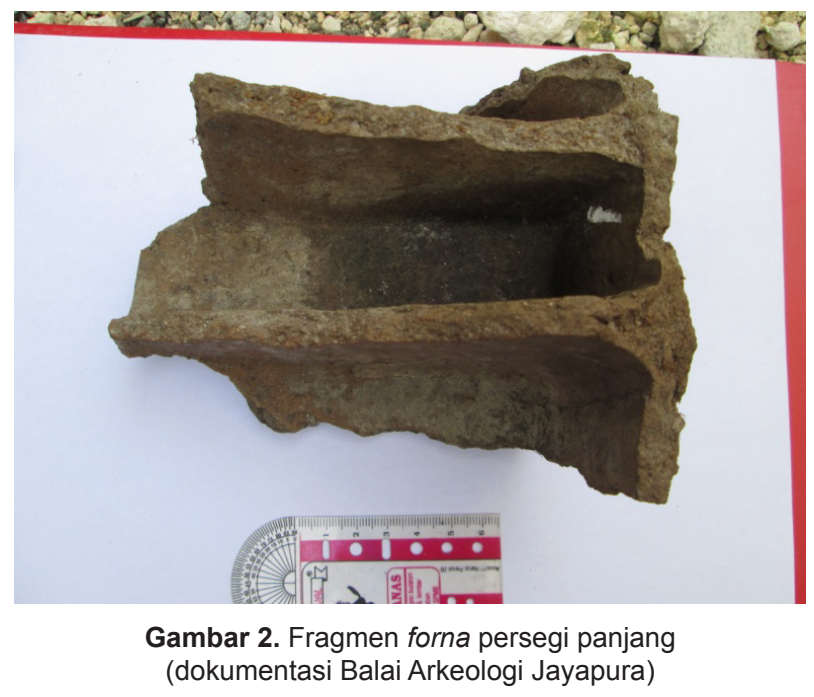

Artefak forna menunjukkan bahwa sagu merupakan makanan pokok yang mudah diperoleh dari hutan di dekat situs. Selain itu juga menggambarkan bahwa menokok sagu merupakan salah satu profesi manusia pendukung situs Mosandurei. Pengamatan terhadap jenis tanah di sekitar situs Mosandurei memungkinkan sebagai bahan pembuat gerabah, asumsi ini didukung oleh keberadaan artefak batu tatap.

Artefak gerabah ditemukan di permukaan tanah dan spit satu hingga spit 7 di kotak B3S3. Sementara pada kotak B2S3 ditemukan pada spit 1 hingga 4, spit 6 hingga 8 . Berdasarkan hal ini, mengindikasikan bahwa gerabah sudah dipergunakan sejak penghunian awal situs.

\section{- Keramik}

Analisis keramik untuk mengenali jaman, dinasti, dan abad dengan mengamati bahan, warna bahan, warna glasir, hiasan, dan teknik hias. Pecahan bagian tepian dan dasar merupakan atribut yang kuat untuk mengidentifikasi jenis keramik. Secara umum, keramik yang ditemukan di situs Mosandurei berupa wadah terbuka, yaitu piring dan mangkuk.

Berdasarkan analisis bentuk terhadap artefak keramik Cina, Vietnam dan Eropa, diketahui berbentuk piring dan mangkuk, yang berfungsi sebagai peralatan makan. Data etnoarkeologi menyebutkan bahwa piring keramik Cina hingga saat ini menjadi mas kawin bagi suku-suku asli Teluk Cenderawasih. Kemungkinan artefak keramik ini diperoleh dari Tidore.

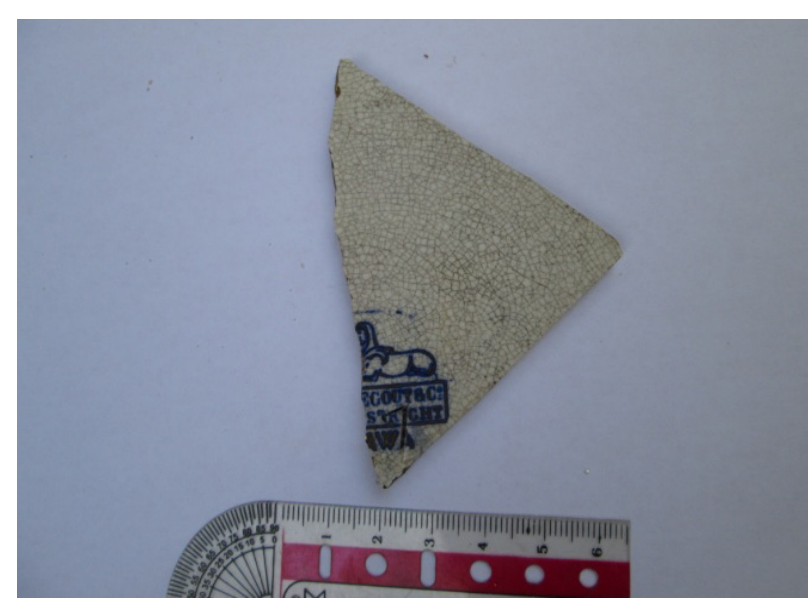

Gambar 3. Fragmen piring Eropa abad 19-20 hasil survei permukaan (dokumentasi Balai Arkeologi Jayapura)

\section{- Artefak berbahan kaca}

Analisis morfologi artefak kaca situs Mosandurei diketahui wadah dan perhiasan.Artefakkacayangdikategorikan sebagai wadah yaitu botol, sedangkan artefak kaca yang dikategorikan sebagai perhiasan yaitu manik-manik. Analisis morfologi botol yang ditemukan, diketahui leher dengan bentuk bundar, bahu landai, badan dengan bentuk dasar bulat, kaki dengan bentuk datar. Warna botol hijau, menunjukkan teknik pewarnaan kaca dibuat dengan cara menambahkan oksidasi krom. 
Botol Eropa berfungsi untuk tengahnya. Manik-manik dirangkai menyimpan anggur selama pelayaran. satu persatu pada seutas benang, Berdasarkan catatan sejarah, sejak dipakai sebagai perhiasan kalung atau abad ke-17, kapal Eropa mulai berlayar di perairan Nabire.

Pelaut Belanda, Jan Willem Schouten dan Jaques le Meire pada tahun 1616 melakukan pelayaran di pantai utara Papua (Budjang, 1963: 116). Jacob Wey Land melakukan pelayaran ke Teluk Cenderawasih tahun 1705 dengan kapal Geelvink, Kraanvogel dan Nova Guinea. Pelayaran ini dilanjutkan oleh A. B. Meyer pada tahun 1873 (Sujatni, 1963: 139). Keberadaan artefak botol di situs Mosandurei menunjukkan telah terjadi kontak dengan pelaut Eropa.

Temuan fragmen botol hanya di permukaan tanah, spit 1 kotak B3S3, spit 1 kotak B3S2. Fragmen keramik ditemukan di permukaan tanah, spit 1 kotak B3S3, spit 1 dan spit 2 kotak B3S2. Artefak ini tidak ditemukan di spit selanjutnya. Hal ini menunjukkan bahwa di akhir penghunian situs telah terjadi penambahan variasi jenis wadah yang digunakan.

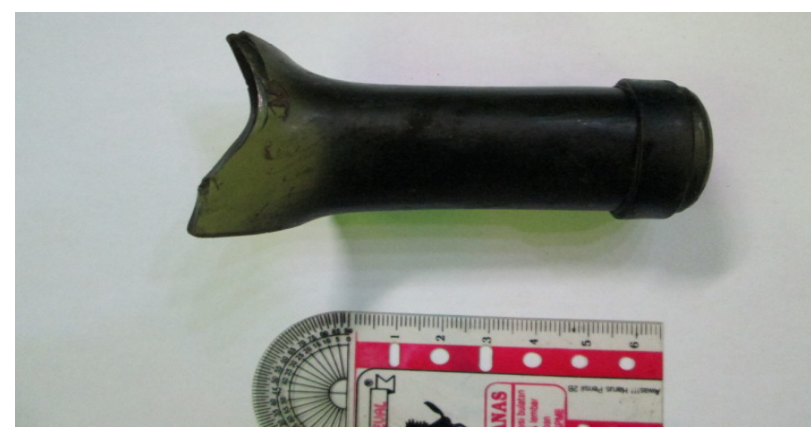

Gambar 4. Fragmen botol

(dokumentasi Balai Arkeologi Jayapura)

Analisis morfologi pada manikmanik situs Mosandurei berbentuk bulat, kubus, tabung, terdapat lubang di bagian gelang. Temuan artefak manik-manik di permukaan tanah, spit 1 dan 2 kotak B2S3, spit 3 kotak B3S3 menunjukkan bahwa manusia pendukung situs Mosandurei telah mengenal perhiasan tubuh. Berdasarkan pengamatan terhadap temuan sekonteks dan dalam lapisan tanah yang sama yaitu fragmen keramik, dan fragmen botol, mengindikasikan bahwa keberadaan ketiga artefak tersebut dalam waktu (zaman) yang sama.

Selain itu pengamatan terhadap lingkungan sekitar situs, tidak ditemukan bahan bahan baku pembuat manikmanik. Hal ini mengindikasikan bahwa manik-manik berasal dari luar situs. Manik-manik pada waktu itu diduga juga berfungsi sebagai alat tukar, alat pelengkap bersifat aksesoris, dan mas kawin. Secara etnoarkeologi terlihat pada suku Sentani yang masih mempergunakan manik-manik sebagai mas kawin dan pembayaran adat.

Perdagangan adalah proses interaksi antara individu atau kelompok sosial yang satu dengan lainnya untuk memperoleh komoditas. Berdasarkan catatan sejarah (Muller, 2008: 86-89) menunjukkan bahwa pada masa Kesultanan Tidore, pelaut dari Teluk Cenderawasih berlayar hingga Tidore. Para pelaut ini membawa kulit kayu masohi, mutiara, kulit penyu, burung cenderawasih, dan kopra. Sekembali dari Tidore, mereka membawa alat-alat dari besi, manik-manik, keramik Cina, gerabah dan kain. 


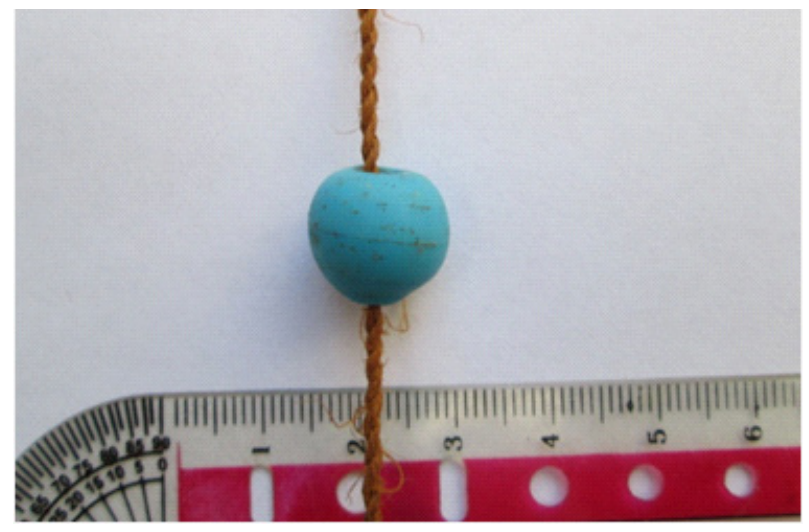

Gambar 5. Manik-manik (dokumentasi Balai Arkeologi Jayapura)

\section{- Alat batu}

Analisis artefak batu yang ditemukan adalah alat penggerus, bentuk silinder yang terdiri atas bagian keliling permukaan dan bagian ujung. Alat ini berfungsi untuk penghalus atau pelumat. Berasal dari jenis batu basal.

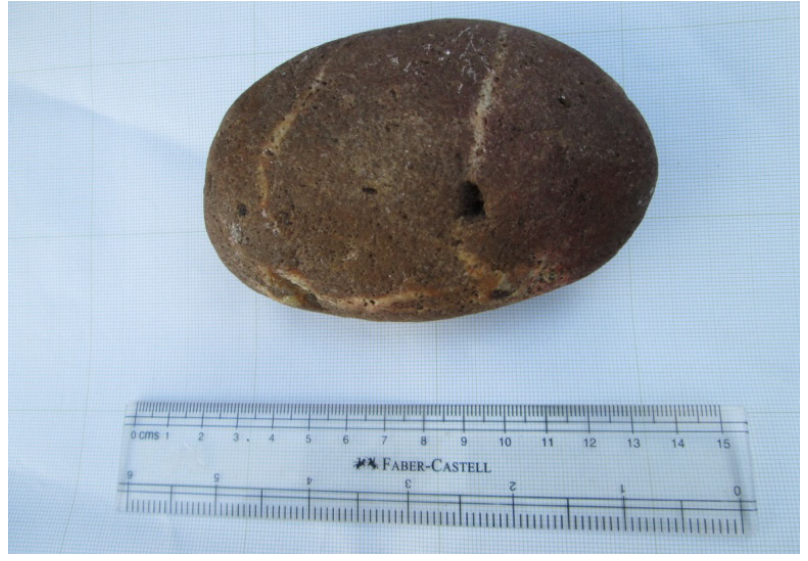

Gambar 6. Artefak batu (dokumentasi Balai Arkeologi Jayapura)

\section{- Ekofak}

Ekofak yang ditemukan yaitu cangkang moluska dalam berbagai jenis, fragmen tulang binatang, arang dan fragmen gigi. Terdapat jenis moluska tertentu yang dominan ditemukan maka dapat diasumsikan bahwa moluska jenis ini merupakan makanan favorit, selain itu diperkirakan sangat mudah dalam mendapatkannya. Cangkang moluska utuh ataupun pecahan, diindikasikan sebagai sampah bekas sisa makanan manusia pendukung situs Mosandurei. Moluska yang dikonsumsi diperoleh dari hutan bakau dan muara sungai Lagari.

Kondisi cangkang utuh, dengan warna yang tidak berubah masih sesuai dengan aslinya mengindikasikan bahwa moluska tidak diproses sebelum dikonsumsi (dikonsumsi mentah) atau direbus. Moluska famili veneridae dan archidae dikonsumsi langsung dengan cara membuka bagian pinggir dari sisi panjang moluska (width) untuk kemudian diambil isi dagingnya. Sedangkan famili tridacnidae dibuka dengan merusak setengah dari bagian cangkang moluska atau dengan merusak bagian badan moluska di sekitar bagian varik (alur-alur vertikal pada badan) sehingga badan moluska berlubang. Moluska famili stromboidae, dengan cara merusak setengah dari bagian cangkang moluska, untuk mengeluarkan isinya. Moluska yang dikonsumsi diperoleh dari hutan bakau dan muara sungai.

Berdasarkan ekofak tulang, menunjukkan bahwa mereka juga melakukan perburuan binatang, yang diperoleh dari hutan di sekitar situs. Temuan arang merupakan bukti aktivitas aktivitas pembakaran atau memasak yang dilakukan oleh manusia penghuni situs Mosandurei. 


\section{PENUTUP}

Berdasarkan analisis data maka diinterpretasikan bahwa situs Mosandurei merupakan situs hunian prasejarah yang berlanjut hingga masa sejarah. Situs ini terletak di atas Bukit Mosandurei. Kondisi permukaan tanah di puncak bukit yang relatif datar, sehingga dapat dimanfaatkan sebagai hunian. Keletakan situs yang dekat dengan hutan sagu, sungai, dan teluk, sangat memudahkan dalam pencarian sumber makanan dan sumber air. Hunian di atas bukit memiliki nilai strategis dalam memantau aktivitas pelayaran di pesisir Teluk Cenderawasih dan memantau wilayah dari serangan musuh. Berdasarkan temuan manik-manik, fragmen gerabah, fragmen keramik Cina, fragmen keramik Eropa serta keletakan geografis situs yang strategis, penduduk Napan pada masa lalu telah menjalin kontak perdagangan dengan luar Papua. 


\section{DAFTAR PUSTAKA}

Atmosudiro, Sumijati. 1995. "Gerabah dan Kajian Kawasan: Studi Kasus Kompleks Kebudayaan Buni Jawa Barat" dalam Berkala Arkeologi Tahun XV-Edisi Khusus-1995. Balai Arkeologi Yogyakarta. HIm. 123-132.

Binford, Lewis R. 1972. Archaeological Perspective. New York: Seminar Press.

Budjang, Anis. 1963. "Orang Biak Numfor" dalam Koentjaraningrat dan Harsja W. Bachtiar (Ed.), Penduduk Irian Barat. Jakarta: Penerbitan Universitas. HIm. 113-135.

Butzer, K. W. 1964. Environment and Archaeology. London: Methuen.

Earle, Timothy K. 1982. Prehistoric Economics and the Archaeology of Exchange. New York: Academic Press.

Fairyo, Klementin dan Marlin Tolla. 2011. "Penelitian Arkeologi di Distrik Napan, Kabupaten Nabire, Provinsi Papua". Laporan Penelitian Arkeologi. Balai Arkeologi Jayapura.

Muller, Kal. 2008. Mengenal Papua. Daisy World Books.

Nayati, Widya. 1995. "Kegiatan Perdagangan: Suatu Penjelasan Berdasarkan Teori Simbolis", dalam Berkala Arkeologi Tahun XV-Edisi Khusus-1995. Balai Arkeologi Yogyakarta. Hlm.96-104.

Redaksi, Dewan 2008. Metode Penelitian Arkeologi. Jakarta: Pusat Penelitian dan Pengembangan Arkeologi Nasional.

Sharer, Robert J. dan Wendy Ashmore. 1979. Fundamentals of Archaeology. California: The Benjamin/ Cummings Publishing Company, Inc.

Shiffer, Michael B. 1976. Behavioral Archaeology. New York: Academic Press.

Sujatni. 1963. "Orang Waropen" dalam Koentjaraningrat dan Harsja W. Bachtiar (Ed.), Penduduk Irian Barat. Jakarta: Penerbitan Universitas. HIm. 136-158.

\section{INTERNET}

http://nabirekab.go.id diakses 19 Januari 2015. 